\title{
Analisis Kualitas Layanan PPDB Online di SMA Xaverius 2 Palembang Menggunakan Metode WebQual 4.0
} Analysis of PPDB Online Service Quality at Xaverius 2 Palembang High School Using The WebQual 4.0 Method

\author{
Yohanes Dwi Prakosa ${ }^{1}$, Dien Novita ${ }^{2}$, Dorie P. Kesuma ${ }^{3}$ \\ ${ }^{1,2,3}$ Program Studi Sistem Informasi, STMIK GI MDP \\ E-mail: ${ }^{1}$ yohanesprakosa29@gmail.com, ${ }^{2}$ dien@mdp.ac.id, ${ }^{3}$ dpkesuma@ staff.mdp.ac.id
}

\begin{abstract}
Abstrak
SMA Xaverius 2 Palembang adalah salah satu sekolah swasta yang ada di Palembang. SMA Xaverius 2 menggunakan website PPDB online untuk menerima dan menyeleksi calon peserta didik. Pendaftaran Peserta Didik Baru (PPDB) adalah sarana bagi peserta didik untuk mendaftarkan diri sebagai calon peserta didik baru jika mereka tidak bisa datang langsung ke SMA Xaverius 2 Palembang. Tujuan dari penelitian ini adalah untuk mengetahui apakah kualitas layanan PPDB online SMA Xaverius 2 Palembang berpengaruh terhadap kepuasan peserta didik yang telah medaftar menggunakan website PPDB online di SMA Xaverius 2 Palembang. Penelitian ini menggunakan metode WebQual 4.0 yang terdiri dari 3 variabel bebas, yaitu usability, information quality, dan interaction quality serta variabel terikat user satisfaction. Untuk mengolah data yang telah didapat, penulis menggunakan software AMOS, Excel, dan SPSS, agar dapat membandingkan hasil yang diperoleh. Dari hasil pengolahan data diperoleh hasil yang sama untuk ketiga software statistik yang digunakan. Dari hasil uji t yang telah dilakukan, menunjukan semua variabel bebas tidak berpengaruh dan tidak signifikan terhadap variabel terikat. Nilai koefisien determinasi $\mathrm{R}^{2}$ diperoleh sebesar 0,510 yang berarti bahwa variabel user satisfaction yang dapat dijelaskan oleh variabel bebas hanya sebesar $51 \%$. Jadi, dari hasil penelitian menunjukkan kualitas dari layanan PPDB online di SMA Xaverius 2 Palembang belum cukup baik.
\end{abstract}

Kata kunci: PPDB online, kualitas layanan, WebQual 4.0, software statistik, user satisfaction

\begin{abstract}
SMA Xaverius 2 Palembang is one of the private schools in Palembang. SMA Xaverius 2 has used the PPDB online website to accept and select prospective students. PPDB online is a facility for students to register as prospective new students if they cannot come directly to Xaverius 2 Palembang High School. The purpose of this study was to determine whether the quality of PPDB online services at Xaverius 2 Palembang High School had an effect on the satisfaction of students who had registered using the PPDB online website at Xaverius 2 Palembang High School. This study uses the WebQual 4.0 method which consists of 3 independent variables, namely usability, information quality, and interaction quality. Then a dependent variable namely user satisfaction. To process the data that has been obtained, the authors use AMOS, Excel, and SPSS software to compare the results obtained. From the results of data processing obtained the same results for the three statistical software used. From the results of the t test that has been done, it shows that all independent variables have no effect and are not significant to dependent variable. The coefficient of determination $R^{2}$ is 0,510 which means that the user satisfaction which can be explained by the independent variables is only $51 \%$. So, the results of the research show that the quality of online PPDB services at Xaverius 2 Palembang High School is not good enough.
\end{abstract}

Keywords: PPDB online, service quality, WebQual 4.0, staistic software, user satisfaction 


\section{PENDAHULUAN}

Perkembangan teknologi informasi sangat berpengaruh terhadap kegiatan penyebaran informasi. Teknologi informasi sendiri merupakan teknologi yang dapat digunakan untuk mengolah data, yang di dalamnya terdapat sistem kerja baik dalam hal memproses, mendapatkan, menyusun, memanipulasi, serta menyimpan data dengan berbagai cara, dimana berguna untuk menghasilkan informasi yang lebih berkualitas dalam arti informasi yang diberikan relevan dan tepat waktu.

Teknologi khususnya dalam dunia pendidikan sangat membantu baik untuk calon peserta didk maupun guru. Pemanfaatan teknologi informasi dalam dunia pendidikan membantu guru dalam proses belajar mengajar seperti penggunaan komputer, proyektor, dan lain-lain sehingga mempermudah guru untuk memaparkan pelajaran yang diberikan kepada peserta didik, Dari sisi internet, mempermudah peserta didik dalam mencari bahan untuk mengerjakan tugas dan mencari materi untuk belajar. Sehingga ilmu yang didapatkan lebih luas dan berkembang. Namun dalam penggunaan teknologi informasi maupun sistem informasi di sekolah, tidak hanya sebatas membantu dalam proses belajar mengajar, dapat juga berupa website sekolah yang digunakan untuk menyebarkan informasi kepada calon peserta didk dan masyarakat umum. Salah satu nya adalah penggunaan website Penerimaan Peserta Didik Baru (PPDB) yang digunakan untuk pendaftaran calon peserta didik baru.

SMA Xaverius 2 Palembang memanfaatkan website ini sebagai sumber informasi bagi masyarakat umum dan bagi calon peserta didik yang ingin melanjutkan pendidikan ke SMA Xaverius 2 Palembang. Informasi yang dapat dilihat di website SMA Xaverius 2 Palembang antara lain profil sekolah, berita sekolah, kontak sekolah, pengumuman Ujian Nasioanl, dan PPDB. SMA Xaverius 2 Palembang menggunakan PPDB online sebagai salah satu media untuk menyaring peserta didik baru yang akan mendaftar ke SMA Xaverius 2 Palembang. Aplikasi PPDB online ini digunakan dan dimanfaatkan oleh calon peserta didik dan pihak sekolah agar memudahkan proses penerimaan dan penyeleksian peserta didik baru. Dengan penggunaan website PPDB memberikan kemudahan bagi orang tua dan calon peserta didik baru dalam mengetahui informasi mengenai pelaksanaan seleksi penerimaan peserta didik baru, melakukan pendaftaran serta melakukan pemantauan hasil seleksi karena dapat dengan mudah diakses melalui gadget atau perangkat lain yang terkoneksi dengan internet [1]. Untuk mengetahui kualitas dari layanan PPDB online SMA Xaverius 2 Palembang terhadap calon peserta didik yang sudah pernah melakukan pendaftaran PPDB online, apakah calon peserta didik tersebut dimudahkan atau mengalami kesulitan dalam melakukan pendaftaran untuk masuk ke SMA Xaverius 2 Palembang, maka diperlukan pengukuran kualitas dari layanan PPDB. Dalam penelitian ini metode dasar yang digunakan untuk mengukur kualitas dari website terhadap kepuasan pengguna adalah dengan menggunakan metode dasar WebQual 4.0. Hal ini didasarkan penelitian [2] bahwasanya saat ini metode webqual salah satu metode yang paling baik digunakan untuk mengukur kualitas web.

Penelitian [3] menjelaskan WebQual sudah mulai dikembangkan sejak tahun 1998 dan telah mengalami beberapa iterasi dalam penyusunan dimensi dan butir-butir pertanyaannya. Penelitian yang menggunakan WebQual 4.0 untuk mengukur kualitas website yang dikelola oleh Organization for Economic Cooperation and Development (OECD). WebQual 4.0 tersebut disusun berdasarkan penelitian pada tiga area yaitu: Pertama, kualitas informasi dari penelitian sistem informasi. Kedua, interaksi dan kualitas layanan dari penelitian kualitas sistem informasi, e-commerce, dan pemasaran. Ketiga, usability dari human-computer interaction. Penelitian [4] menjelaskan bahwa WebQual merupakan salah satu metode pengukuran kualitas website berdasarkan persepsi pengguna akhir. WebQual ini merupakan pengembangan dari ServQual yang telah banyak digunakan untuk pengukuran kualitas jasa. WebQual ini berbasis pada Quality Function Deployment (QFD). 


\section{METODE PENELITIAN}

\subsection{Tahapan Penelitian}

Gambar 1 adalah tahapan penelitian yang dilakukan untuk menganalisis kualitas layanan website PPDB online SMA Xaverius 2 Palembang.

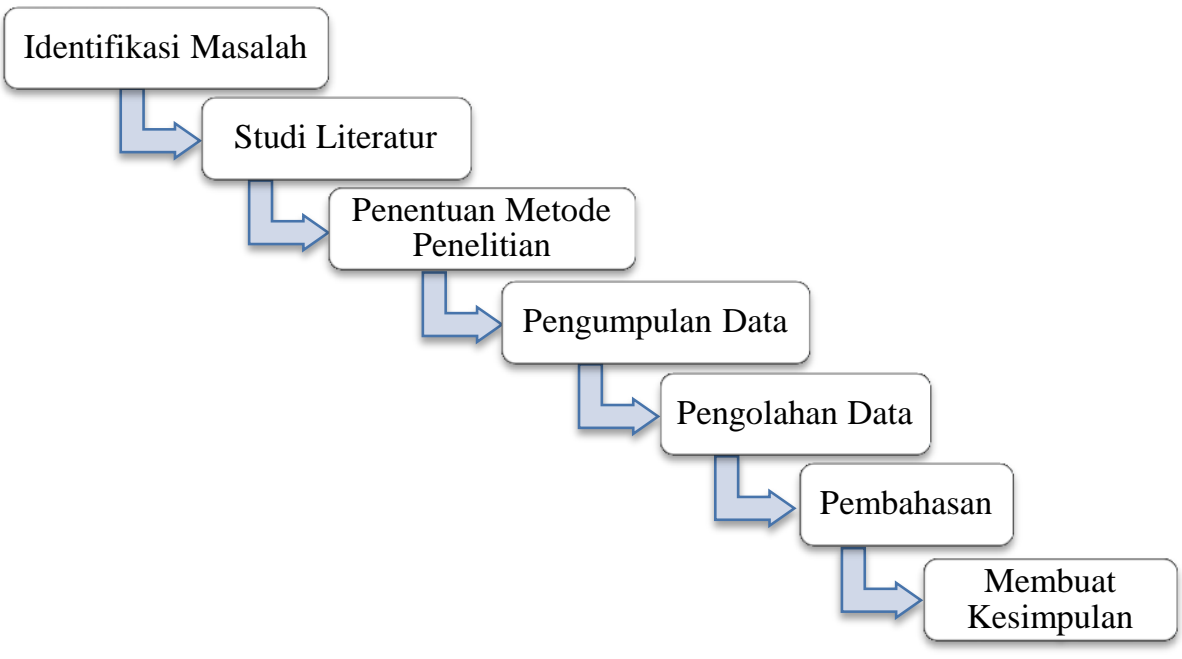

Gambar 1. Tahapan Penelitian

Tahapan identifikasi masalah dilakukan dengan mencari dan menemukan pokok permasalahan apa saja yang ada melalui kegiatan wawancara terhadap guru TIK di SMA Xaverius 2 Palembang dan mengumpulkan data-data yang dibutuhkan. Pada tahap studi literatur, dilakukan dengan cara mencari teori-teori apa saja yang dapat digunakan untuk mendukung penelitian ini. Teori tersebut diperoleh dalam bentuk jurnal. Tahapan penentuan metode penelitian diperoleh berdasarkan hasil penelusuran jurnal-jurnal dan hasil observasi. Peneliti menggunakan metode WebQual 4.0 serta indikator dan variabel yang sesuai dengan penelitian dari hasil penelusuran jurnal tersebut. Selanjutnya dilakukan penyusunan kuisioner, menyebarkan kuisioner, lalu pengumpulan data dari pengolahan hasil pengisian kuisioner. Pengolahan data dilakukan dengan melakukan pengujian menggunakan software AMOS, Excel, dan SPSS. Setelah diperolehhasil olah data, selanjutnya hasil tersebut di jelaskan apakah telah menjawab masalah penelitian dan mendukung hipotesis penelitian. Pada tahap terakhir yaitu membuat kesimpulan akan dibuat bentuk ringkasan kesimpulan penelitian yang telah dilakukan apakah telah menjawab permasalahan.

\section{2 Populasi dan Sampel}

PPDB Online baru digunakan pada tahun 2016 di SMA Xaverius 2 Palembang sebagai salah satu fasilitas yang disiapkan sekolah untuk proses pendaftaran peserta didik baru. Sebagian besar peserta didik secara langsung datang untuk melakukan proses pendaftaran, karena masih banyak yang belum mengetahui jika pendaftaran dapat dilakukan secara online. Jumlah sampel yang digunakan dalam penelitian yaitu sebanyak 35 responden diambil dari jumlah peserta didik aktif tahun pelajaran 2019/2020 di SMA Xaverius 2 yang melakukan pendaftaran peserta didik baru menggunakan PPDB online.

\subsection{Variabel Penelitian}

Berdasarkan penelitian terdahulu dan literatur yang ada, variabel dan indikator yang digunakan pada penelitian ini merujuk pada jurnal yang dapat dilihat pada Tabel 1 berikut: 
JTSI, Vol. 1, No. 2, September 2020: 199-211

Tabel 1. Indikator Penelitian

\begin{tabular}{|c|c|c|c|}
\hline Dimensi & Kode & Indikator & Sumber \\
\hline \multirow{7}{*}{ Usability } & $\mathrm{X} 1.1$ & $\begin{array}{l}\text { mudah dalam mengoperasikan } \\
\text { website }\end{array}$ & \multirow{7}{*}[5]{} \\
\hline & $\mathrm{X} 1.2$ & $\begin{array}{l}\text { interaksi antara website dengan } \\
\text { pengguna jelas dan mudah } \\
\text { dipahami }\end{array}$ & \\
\hline & $\mathrm{X} 1.3$ & $\begin{array}{l}\text { mudah untuk bernavigasi dengan } \\
\text { website }\end{array}$ & \\
\hline & $\mathrm{X} 1.4$ & website mudah digunakan & \\
\hline & $\mathrm{X} 1.5$ & $\begin{array}{l}\text { website memiliki tampilan yang } \\
\text { menarik }\end{array}$ & \\
\hline & $\mathrm{X} 1.6$ & $\begin{array}{l}\text { design sesuai dengan jenis } \\
\text { website }\end{array}$ & \\
\hline & $\mathrm{X} 1.7$ & $\begin{array}{l}\text { website menciptakan pengalaman } \\
\text { positif bagi pengguna }\end{array}$ & \\
\hline \multirow{7}{*}{$\begin{array}{c}\text { Information } \\
\text { Quality }\end{array}$} & $\mathrm{X} 2.1$ & informasi yang akurat & \multirow{7}{*}[5]{} \\
\hline & $\mathrm{X} 2.2$ & informasi yang dapat dipercaya & \\
\hline & $\mathrm{X} 2.3$ & informasi yang tepat waktu & \\
\hline & $\mathrm{X} 2.4$ & informasi yang relevan & \\
\hline & $\mathrm{X} 2.5$ & $\begin{array}{l}\text { informasi yang mudah } \\
\text { dimengerti }\end{array}$ & \\
\hline & $\mathrm{X} 2.6$ & $\begin{array}{l}\text { memberikan informasi dengan } \\
\text { tingkat detail yang tepat }\end{array}$ & \\
\hline & $\mathrm{X} 2.7$ & $\begin{array}{l}\text { tampilan informasi dengan } \\
\text { format yang sesuai }\end{array}$ & \\
\hline \multirow{4}{*}{$\begin{array}{c}\text { Service } \\
\text { Interaction } \\
\text { Quality }\end{array}$} & $\mathrm{X} 3.1$ & mempunyai reputasi yang baik & \multirow{4}{*}[1]{} \\
\hline & $\mathrm{X} 3.2$ & Informasi pribadi aman & \\
\hline & $\mathrm{X} 3.3$ & ruang personalisasi & \\
\hline & $\mathrm{X} 3.4$ & $\begin{array}{l}\text { memberikan pelayanan yang } \\
\text { sesuai }\end{array}$ & \\
\hline \multirow{5}{*}{$\begin{array}{c}\text { User } \\
\text { Satisfaction }\end{array}$} & Y.1 & kemudahan untuk mengakses & \multirow{5}{*}{ [1] } \\
\hline & Y.2 & pelayanan yang sesuai fungsinya & \\
\hline & Y.3 & efisiensi dan transparan & \\
\hline & Y.4 & informasi yang bermanfaat & \\
\hline & Y.5 & $\begin{array}{l}\text { adanya kepuasan pengguna } \\
\text { terhadap kualitas website }\end{array}$ & \\
\hline
\end{tabular}

\subsection{Hipotesis Penelitian}

Penelitian ini menggunakan desain kausal yang bertujuan untuk menganalisis hubungan antara satu variabel dengan variabel lainnya. Desain kausal digunakan untuk menganalisis secara empiris variabel-variabel yang berpengaruh terhadap kepuasan pengguna (user satisfaction), yakni variabel usability, information quality, service interaction quality. berdasarkan Model WebQual 4.0. Gambar 2 berikut adalah hipotesis penelitian berdasarkan model WebQual 4.0 . 


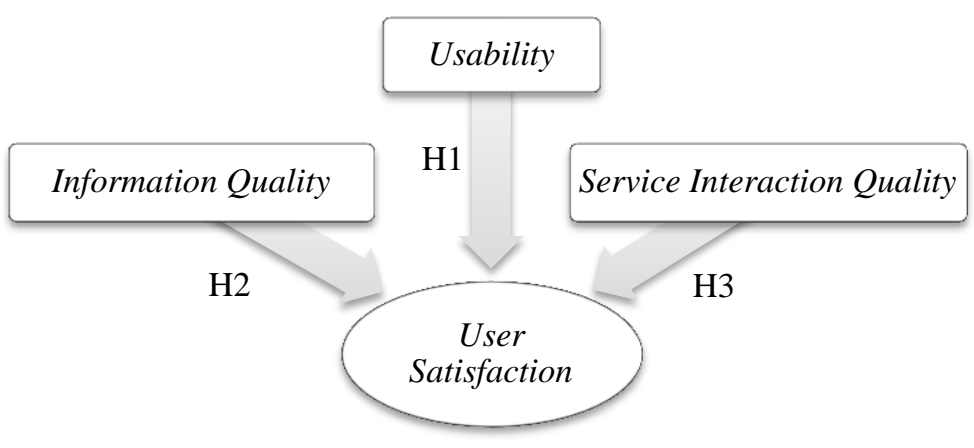

Gambar 2. Hipotesis Penelitian

Berdasarkan Gambar 2, hipotesis penelitian dapat dijelaskan sebagai berikut:

1. H1 : Kualitas kegunaan (usability) mempunyai pengaruh signifikan terhadap kepuasan pengguna (user satisfaction).

H0 : Kualitas kegunaan (usability) tidak mempunyai pengaruh yang signifikan terhadap kepuasan pengguna (user satisfaction).

2. H2 : Kualitas informasi (information quality) mempunyai pengaruh signifikan terhadap kepuasan (user satisfaction).

H0 : Kualitas informasi (information quality) tidak mempunyai pengaruh yang signifikan terhadap kepuasan pengguna (user satisfaction).

3. H3 : Kualitas interaksi layanan (service interaction quality) mempunyai pengaruh signifikan terhadap kepuasan pengguna (user satisfaction).

H0 : Kualitas interaksi layanan (service interaction quality) tidak mempunyai pengaruh yang signifikan terhadap kepuasan pengguna (user satisfaction).

\section{HASIL DAN PEMBAHASAN}

Merujuk pada jurnal [6] yang menggunakan 3 software perhitungan yaitu SPSS, AMOS dan Excel. Maka di penelitian ini penulis juga menggunakan 3 software perhitungan yaitu SPSS, AMOS dan Excel agar dapat dipahami teknik perhitungannya dan memberikan perbandingan hasil yang diperoleh untuk meyakinkan kesimpulan yang di dapat.

Seperti penelitian [7] hasil penelitian pengukuran kualitas web menggunakan metode WebQual ini diharapkan dapat membantu manajemen dan pihak terkait untuk mengambil langkah-langkah yang diperlukan dalam rangka memperbaiki dan meningkatkan kualitas web.

\section{1 Karakteristik Responden}

Data responden dikelompokan berdasarkan kelas, jurusan dan jenis kelamin. Gambar 3 merupakan karakteristik responden berdasarkan kelas.

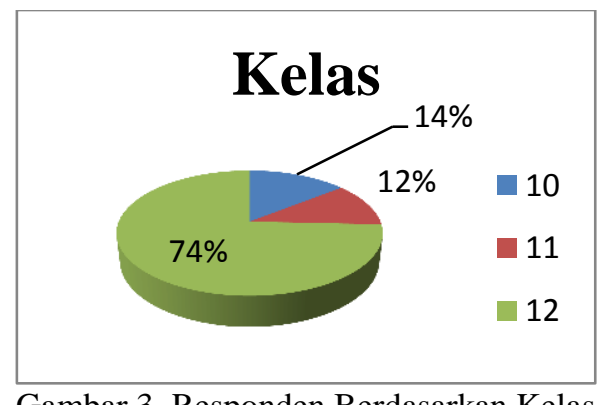

Gambar 3. Responden Berdasarkan Kelas 
Diagram diatas menunjukkan bahwa responden paling banyak berada di kelas 12 sebanyak 26 orang dengan persentase $74,3 \%$. kemudian sebanyak 5 orang di kelas 11 dengan presentase $14 \%$, dan 4 orang di kelas 11 dengan presentase 12\%. Gambar 4 adalah karakteristik responden berdasarkan jurusan.

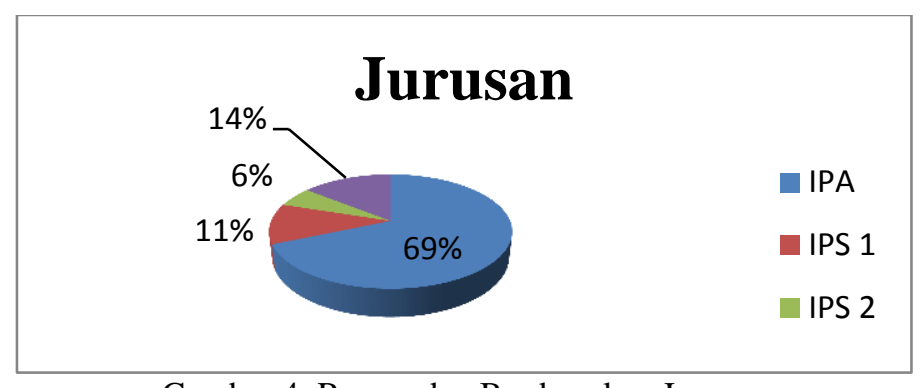

Gambar 4. Responden Berdasarkan Jurusan

Diagram diatas menunjukkan bahwa responden paling banyak ada di jurusan IPA sebanyak 24 orang dengan persentase $68.6 \%$. Di urutan kedua adalah jurusan IPS 3 sebanyak 5 orang dengan presentase $14 \%$. Kemudian IPS 1 sebanyak 4 orang dengan presentasi $11 \%$. Di posisi terakhir ada IPS 2 dengan jumlah 2 orang dengan presenntase 6\%. Gambar 5 adalah responden berdasarkan jenis kelamin.

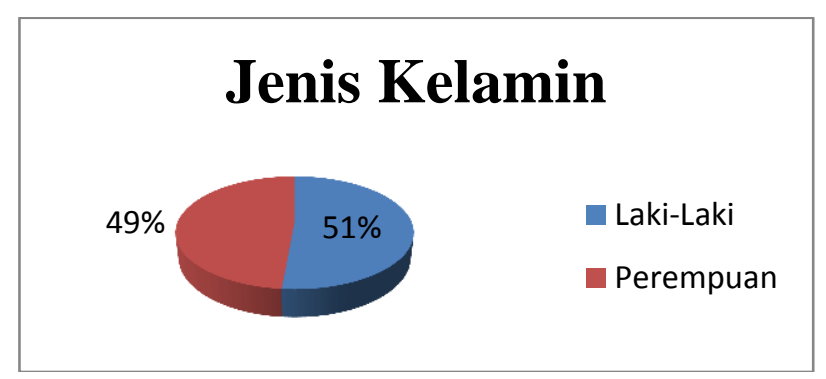

Gambar 5. Responden Berdasarkan Jenis Kelamin

Diagram diatas menunjukkan bahwa responden paling banyak dengan jenis kelamin laki-laki, sebanyak 18 orang dengan persentase $51,4 \%$. Sedangkan responden berjenis kelamin perempuan, sebanyak 17 orang dengan presentase $48,6 \%$.

\section{2 Uji Validitas dan Reliabilitas}

Uji validitas digunakan untuk mengukur valid atau tidaknya kuisioner. Suatu kuisioner dikatakan valid jika pertanyaan pada kuisioner tersebut mampu mengukur variabel yang ingin diukur [8]. Tabel 2 adalah hasil perhitungan uji validitas.

Tabel 2. Uji Validitas

\begin{tabular}{|c|c|c|c|c|}
\hline Indikator & $\mathbf{r}_{\text {tabel }}$ & $\mathbf{r}_{\text {hitung }}$ & Signifikan $\boldsymbol{\alpha}$ & Keterangan \\
\hline $\mathrm{X} 1.1$ & 0,3338 & 0,833 & 0,000 & Valid \\
\hline $\mathrm{X} 1.2$ & 0,3338 & 0,733 & 0,000 & Valid \\
\hline $\mathrm{X} 1.3$ & 0,3338 & 0,777 & 0,000 & Valid \\
\hline $\mathrm{X} 1.4$ & 0,3338 & 0,803 & 0,000 & Valid \\
\hline $\mathrm{X} 1.5$ & 0,3338 & 0,588 & 0,000 & Valid \\
\hline $\mathrm{X} 1.6$ & 0,3338 & 0,738 & 0,000 & Valid \\
\hline $\mathrm{X} 1.7$ & 0,3338 & 0,755 & 0,000 & Valid \\
\hline $\mathrm{X} 2.1$ & 0,3338 & 0,931 & 0,000 & Valid \\
\hline $\mathrm{X} 2.2$ & 0,3338 & 0,904 & 0,000 & Valid \\
\hline $\mathrm{X} 2.3$ & 0,3338 & 0,907 & 0,000 & Valid \\
\hline
\end{tabular}




\begin{tabular}{|c|c|c|c|c|}
\hline X2.4 & 0,3338 & 0,866 & 0,000 & Valid \\
\hline X2.5 & 0,3338 & 0,711 & 0,000 & Valid \\
\hline X2.6 & 0,3338 & 0,866 & 0,000 & Valid \\
\hline X2.7 & 0,3338 & 0,830 & 0,000 & Valid \\
\hline X3.1 & 0,3338 & 0,836 & 0,000 & Valid \\
\hline X3.2 & 0,3338 & 0,856 & 0,000 & Valid \\
\hline X3.3 & 0,3338 & 0,814 & 0,000 & Valid \\
\hline X3.4 & 0,3338 & 0,845 & 0,000 & Valid \\
\hline Y.1 & 0,3338 & 0,687 & 0,000 & Valid \\
\hline Y.2 & 0,3338 & 0,720 & 0,000 & Valid \\
\hline Y.3 & 0,3338 & 0,749 & 0,000 & Valid \\
\hline Y.4 & 0,3338 & 0,736 & 0,000 & Valid \\
\hline Y.5 & 0,3338 & 0,724 & 0,000 & Valid \\
\hline
\end{tabular}

Dari hasil uji validitas diatas, dapat diambil kesimpulan bahwa semua item pernyataan tersebut memiliki nilai rhitung > rtabel dan nilai signifikansi p-value lebih kecil dari 0,05. Sehingga semua item pernyataan tersebut valid dan dapat digunakan dalam penelitian ini.

Reliabilitas berkenaan dengan tingkat ketetapan hasil pengukuran. Kiesioner dikatakan reliabel jika dapat memberikan hasil relative sama pada saat dilakukan pengukuran kembali pada objek yang berlainan pada waktu yang berbeda atau memberikan hasil yang tepat [9]. Tabel 3 adalah hasil perhitungan uji reliabilitas.

Tabel 3. Uji Reliabilitas

\begin{tabular}{|l|c|c|c|}
\hline \multicolumn{1}{|c|}{ Variabel } & $\begin{array}{c}\text { Cronbach } \\
\text { Alpha }\end{array}$ & $\begin{array}{c}\text { Standar } \\
\text { Reliabilitas }\end{array}$ & Keterangan \\
\hline usability & 0,864 & 0,7 & Reliabel \\
\hline information quality & 0,941 & 0,7 & Reliabel \\
\hline service interaction quality & 0,855 & 0,7 & Reliabel \\
\hline user satisfaction & 0,764 & 0,7 & Reliabel \\
\hline
\end{tabular}

Dari hasil uji reliabilitas semua variabel, diperoleh nilai-nilai Cronbach Alpha dari semua variabel penelitian ini menunjukkan lebih besar dari nilai 0,7 maka demikian jawabanjawaban responden dari variabel-variabel penelitian tersebut reliabel, sehingga dapat digunakan untuk penelitian berikut.

\section{3 Analisis Korelasi}

Analisis korelasi parsial ini digunakan untuk mengetahui kekuatan hubungan antara korelasi kedua variabel dimana variabel lainnya yang dianggap berpengaruh dikendalikan atau dibuat tetap (sebagai variabel kontrol) [9].

Tabel 4. Analisis Korelasi Menggunakan SPSS

\begin{tabular}{|c|c|c|c|c|c|}
\hline & & Usability & $\begin{array}{c}\text { Information } \\
\text { Quality }\end{array}$ & $\begin{array}{c}\text { Service } \\
\text { Interaction } \\
\text { Quality } \\
\end{array}$ & $\begin{array}{c}\text { User } \\
\text { Satisfaction } \\
\end{array}$ \\
\hline usability & $\begin{array}{l}\text { Pearson } \\
\text { Correlation } \\
\text { Sig. (2-tailed) } \\
\text { N }\end{array}$ & $\begin{array}{l}1 \\
35\end{array}$ & $\begin{array}{l}0,702^{* *} \\
0,000 \\
35\end{array}$ & $\begin{array}{l}0,760^{* *} \\
0,000 \\
35\end{array}$ & $\begin{array}{l}0,646^{* *} \\
0,000 \\
35\end{array}$ \\
\hline information quality & $\begin{array}{l}\text { Pearson } \\
\text { Correlation } \\
\text { Sig. (2-tailed) }\end{array}$ & $\begin{array}{l}0,702^{* *} \\
0,000\end{array}$ & 1 & $\begin{array}{l}0,728^{* *} \\
0,000\end{array}$ & $\begin{array}{l}0,633^{* *} \\
0,000\end{array}$ \\
\hline
\end{tabular}




\begin{tabular}{|c|c|c|c|c|c|}
\hline & $\mathrm{N}$ & 35 & 35 & 35 & 35 \\
\hline service interaction quality & $\begin{array}{l}\text { Pearson } \\
\text { Correlation } \\
\text { Sig. (2-tailed) } \\
\mathrm{N} \\
\end{array}$ & $\begin{array}{l}0,760^{* *} \\
0,000 \\
35\end{array}$ & $\begin{array}{l}0,728^{* *} \\
0,000 \\
35 \\
\end{array}$ & 1 & $\begin{array}{l}0,660^{* * *} \\
0,000 \\
35\end{array}$ \\
\hline user satisfaction & $\begin{array}{l}\text { Pearson } \\
\text { Correlation } \\
\text { Sig. (2-tailed) } \\
\mathrm{N}\end{array}$ & $\begin{array}{l}0,646^{* *} \\
0,000 \\
35\end{array}$ & $\begin{array}{l}0,633^{* *} \\
0,000 \\
35\end{array}$ & $\begin{array}{l}0,660^{* *} \\
0,000 \\
35\end{array}$ & 1 \\
\hline
\end{tabular}

Tabel 5. Analisis Korelasi Menggunakan EXCEL

\begin{tabular}{|l|l|l|l|l|}
\hline & \multicolumn{1}{|c|}{ Usability } & $\begin{array}{c}\text { Information } \\
\text { Quality }\end{array}$ & $\begin{array}{c}\text { Service Interaction } \\
\text { Quality }\end{array}$ & $\begin{array}{c}\text { User } \\
\text { Satisfaction }\end{array}$ \\
\hline usability & 1 & & & \\
\hline information quality & 0,70248613 & 1 & & \\
\hline service interaction quality & 0,759557717 & 0,727733423 & 1 & \\
\hline user satisfaction & 0,645926806 & 0,63255978 & 0,660133887 & 1 \\
\hline
\end{tabular}

Tabel 6. Analisis Korelasi Menggunakan AMOS

\begin{tabular}{|l|c|c|c|c|}
\hline & Usability & $\begin{array}{c}\text { Information } \\
\text { Quality }\end{array}$ & $\begin{array}{c}\text { Service } \\
\text { Interaction } \\
\text { Quality }\end{array}$ & $\begin{array}{c}\text { User } \\
\text { Satisfaction }\end{array}$ \\
\hline usability & 1,000 & & & \\
\hline information quality & 0,728 & 1,000 & & \\
\hline service interaction quality & 0,760 & 0,702 & 1,000 & \\
\hline user satisfaction & $\mathbf{0 , 6 6 0}$ & $\mathbf{0 , 6 3 3}$ & $\mathbf{0 , 6 4 6}$ & $\mathbf{1 , 0 0 0}$ \\
\hline
\end{tabular}

Berdasarkan hasil analisis korelasi menggunakan 3 software statistik diperoleh hasil yang tidak jauh berbeda seperti ditunjukkan di Tabel 4, 5, dan 6 . Hasil analisis korelasi diatas dapat disimpulkan sebagai berikut:

1. Berdasarkan hasil korelasi, diperoleh nilai $\mathrm{r}$ hitung usability (X1) terhadap kepuasan pengguna (Y) sebesar 0,646 >0,3338 $\mathrm{r}$ tabel, sehingga terdapat korelasi antara variabel usability dengan variabel user satisfaction. Nilai signifikansi variabel usability sebesar $0,000<0,05$ sehingga terdapat korelasi yang signifikan antara variabel usability dengan variabel user satisfaction.

2. Berdasarkan hasil korelasi, diperoleh nilai $\mathrm{r}$ hitung information quality (X2) terhadap kepuasan pengguna $(\mathrm{Y})$ sebesar 0,633 >0,3338 $\mathrm{r}$ tabel, sehingga terdapat korelasi antara variabel information quality dengan variabel user satisfaction. Nilai signifikansi variabel information quality sebesar $0,000<0,05$ sehingga terdapat korelasi yang signifikan antara variabel Usability dengan variabel user satisfaction.

3. Berdasarkan hasil korelasi, diperoleh nilai $\mathrm{r}$ hitung service interaction quality (X3) terhadap kepuasan pengguna $(\mathrm{Y})$ sebesar 0,660 >0,3338 $\mathrm{r}$ tabel, sehingga terdapat korelasi antara variabel service interaction quality dengan variabel user satisfaction. Nilai signifikansi variabel service interaction quality sebesar $0,000<0,05$ sehingga terdapat korelasi yang signifikan antara variabel usability dengan variabel user satisfaction.

\section{4 Analisis Regresi Linier Berganda}

Analisis regresi linier adalah salah satu alat dalam statistik yang digunakan untuk mengetahui ada atau tidak nya hubungan variabel bebas terhadap variabel tidak bebas (respons) [10]. Dengan menggunakan metode regresi linier berganda didapatkan hasil sebagai berikut: 
Tabel 7. Regresi Linier Berganda SPSS

\begin{tabular}{|ll|l|l|}
\hline \multirow{2}{*}{\multicolumn{2}{|c|}{ Model }} & \multicolumn{2}{c|}{$\begin{array}{c}\text { Unstandardized } \\
\text { Coefficients }\end{array}$} \\
\cline { 3 - 4 } & \multicolumn{2}{|c|}{ B } & Std. Error \\
\hline 1 & (Constant) & 6,948 & 1,929 \\
& usability & 0,161 & 0,129 \\
& information quality & 0,121 & 0,097 \\
\cline { 2 - 3 } service interaction quality & 0,289 & 0,213 \\
\hline
\end{tabular}

Berdasarkan hasil analisis tabel 7 diatas dapat dijelaskan melalui model regresi $\mathrm{Y}=$ $6,948+0,161 X_{1}+0,121 X_{2}+0,289 X_{3}$ sebagai berikut:

1. Konstanta $=6,948$. Artinya jika variabel usability, information quality dan service interaction quality dianggap sama dengan nol, maka variabel user satisfaction mempunyai nilai 6,948 .

2. Koefisien usability $=0,161$. Artinya jika variabel usability mengalami kenaikan sebesar 1 satuan sedangkan variabel lain dianggap konstan, maka variabel dependen yaitu user satisfaction akan mengalami kenaikan sebesar 0,161.

3. Koefisien information quality $=0,121$. Artinya jika variabel information quality mengalami kenaikan sebesar 1 satuan sedangkan variabel lain dianggap konstan, maka variabel dependen yaitu user satisfaction akan mengalami kenaikan sebesar 0,121.

4. Koefisien service interaction quality $=0,289$. Artinya jika variabel service interaction quality mengalami kenaikan sebesar 1 satuan sedangkan variabel lain dianggap konstan, maka variabel dependen yaitu user satisfaction akan mengalami kenaikan sebesar 0,289.

Dengan menggunakan AMOS, diperoleh regresi linier berganda berdasarkan gambar model pada Gambar 6 .

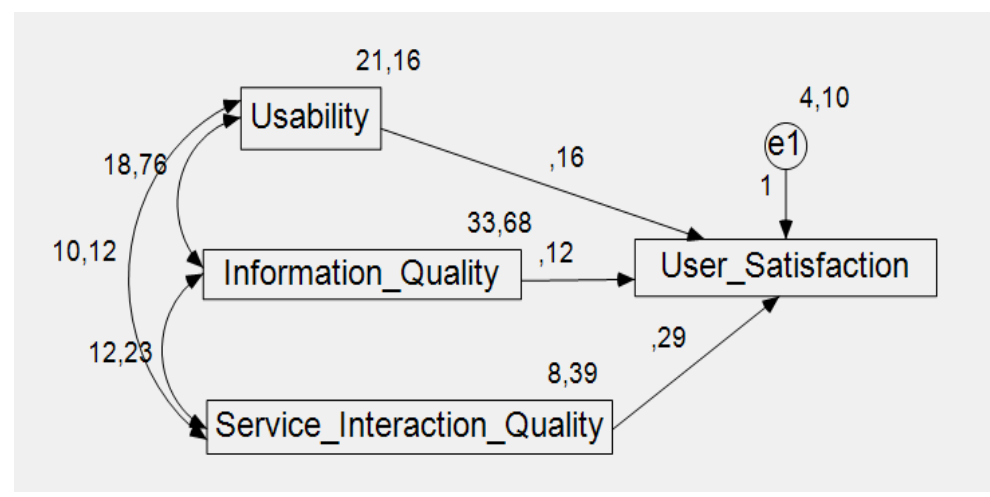

Gambar 6. Model Persamaan Regresi Berganda

Dari model Persamaan Regresi Berganda menggunakan AMOS, diperoleh Persamaan Regresi Berganda sebagai berikut $\mathrm{Y}=0,16 \mathrm{X}_{1}+0,12 \mathrm{X}_{2}+0,29 \mathrm{X}_{3}$ yang tidak jauh berbeda dengan hasil SPSS, hanya saja tidak muncul nilai konstantanya. Untuk lebih jelasnya dapat dilihat di Tabel 8.

Tabel 8. Regresi Linier Berganda Menggunakan AMOS

\begin{tabular}{|c|c|c|c|c|c|c|c|}
\hline & & & Estimate & S.E. & C.R. & $\mathrm{P}$ & Label \\
\hline user satisfaction & & usability & 0,161 & 0,123 & 1,306 & 0,192 & par_1 \\
\hline user satisfaction & $<--$ & Information quality & 0,121 & 0,093 & 1,302 & 0,193 & par_4 \\
\hline user satisfaction & $<--$ & Service interaction quality & 0,289 & 0,203 & 1,424 & 0,154 & par_5 \\
\hline
\end{tabular}




\subsection{Uji Hipotesis}

\section{3. $5.1 \mathrm{Ujit}$}

Uji t digunakan untuk menguji seberapa pengaruh secara parsial variabel independen terhadap variabel dependen. Tujuan penelitian ini adalah untuk mengetahui apakah masingmasing variabel independent mempengaruhi variabel dependen secara signifikan [8].

Tabel 9. Uji t Menggunakan SPSS

\begin{tabular}{|l|l|l|l|}
\hline \multicolumn{2}{|c|}{ Model } & $\mathrm{t}$ & Sig. \\
\hline 1 & (Constant) & 3,601 & 0,001 \\
& Usability & 1,247 & 0,222 \\
& Information Quality & 1,243 & 0,223 \\
& Service Interaction Quality & 1,360 & 0,184 \\
\hline
\end{tabular}

Tabel 9 adalah hasil pengujian t secara parsial menggunakan SPSS, sedangkan Tabel 10 berikut uji t menggunakan Excel.

Tabel 10. Uji t Menggunakan EXCEL

\begin{tabular}{|l|c|l|l|c|}
\hline & Coefficients & Standard Error & T Stat & P-Value \\
\hline intercept & 6,948108804 & 1,929258168 & 3,601440657 & 0,001090554 \\
\hline usability & 0,160811563 & 0,128978588 & 1,246808218 & 0,221806495 \\
\hline information quality & 0,12051581 & 0,096951517 & 1,243052344 & 0,223168418 \\
\hline service interaction quality & 0,289056936 & 0,212597772 & 1,359642356 & 0,183751191 \\
\hline
\end{tabular}

Hasil uji t dapat dijelaskan sebagai berikut:

1. Berdasarkan hasil uji $\mathrm{t}$ (parsial) pada model regresi, diperoleh nilai $\mathrm{t}$ hitung 1,247 dan nilai signifikansi variabel usability sebesar 0,222 >0.05 (taraf signifikansi 5\%). Artinya dapat disimpulkan bahwa secara parsial variabel usability tidak berpengaruh signifikan terhadap user satisfaction.

2. Berdasarkan hasil uji $\mathrm{t}$ (parsial) pada model regresi, diperoleh nilai $\mathrm{t}$ hitung sebesar 1,243 dan nilai signifikansi variabel information quality sebesar 0,223 >0,05 (taraf signifikansi $5 \%$ ). Artinya dapat disimpulkan bahwa secara parsial variabel information quality tidak berpengaruh signifikan terhadap user satisfaction.

3. Berdasarkan hasil uji t (parsial) pada model regresi, diperoleh nilai t hitung sebesar 1,360 dan nilai signifikansi variabel service interaction quality sebesar 0,184 >0,05 (taraf signifikansi 5\%). Artinya dapat disimpulkan bahwa secara parsial variabel service interaction quality tidak berpengaruh signifikan terhadap user satisfaction.

\section{5.1 Uji F}

Uji $\mathrm{F}$ bertujuan untuk mengetahui apakah varibel bebas (independent) secara bersamasama berpengaruh terhadap variabel terikat (dependent) [8].

Tabel 11. Uji F Menggunakan SPSS

\begin{tabular}{|ll|l|l|l|l|c|}
\hline & Model & Sum of Squares & df & Mean Square & F & Sig. \\
\hline 1 & Regression & 149,003 & 3 & 49,668 & 10,737 & $0,000^{b}$ \\
& Residual & 143,397 & 31 & 4,626 & & \\
& Total & 292,400 & 34 & & & \\
\hline
\end{tabular}


Tabel 12. Uji F Menggunakan Excel

\begin{tabular}{|l|l|l|l|l|l|}
\hline & \multicolumn{1}{|c|}{$\boldsymbol{d} \boldsymbol{f}$} & \multicolumn{1}{c}{$\boldsymbol{S S}$} & \multicolumn{1}{c|}{$\boldsymbol{M S}$} & $\boldsymbol{F}$ & Significance $\boldsymbol{F}$ \\
\hline Regression & 3 & 149,0031393 & 49,66771309 & 10,73732785 & $5,33827 \mathrm{E}-05$ \\
\hline Residual & 31 & 143,3968607 & 4,625705185 & & \\
\hline Total & 34 & 292,4 & & & \\
\hline
\end{tabular}

Berdasarkan Tabel 11 dan 12 di atas dapat diperoleh nilai $\mathrm{F}$ hitung yang sama yaitu sebesar 10,737 dengan taraf signifikansi sebesar 0,000. Ini menunjukkan bahwa taraf signifikansi $\mathrm{F}$ hitung lebih kecil dari nilai tingkat signifikansi 0,05. Artinya bahwa variabel usability, information quality dan service interaction quality secara bersama-sama mempunyai pengaruh yang signifikan terhadap user satisfaction. Hal ini sesuai dengan teori yang di kemukakan oleh [8], apabila nilai $\mathrm{F}_{\text {hitung }}>\mathrm{F}_{\text {tabel }}$ dan sig < 0,05 maka uji $\mathrm{F}$ terpenuhi. Artinya semua variabel bebas secara serentak dan signifikan mempengaruhi variabel terikat.

\section{6 Uji Koefisien Determinasi $\left(R_{2}\right)$}

Uji koefisien determinan bertujuan untuk mengukur seberapa jauh kemampuan model dalam menerapkan variasi variabel dependen. Nilai koefisien determinan adalah antara nol dan satu, nilai $\mathrm{R}^{2}$ yang kecil menunjukkan bahwa kemampuan variabel-variabel independent dalam menjelaskan variabel dependen amat terbatas [8].

Tabel 13. Koefisien Determinan Menggunakan SPSS

\begin{tabular}{|l|c|l|l|l|}
\hline Model & R & R Square & $\begin{array}{c}\text { Adjusted R } \\
\text { Square }\end{array}$ & $\begin{array}{c}\text { Std. Error of } \\
\text { the Estimate }\end{array}$ \\
\hline 1 & $0,714^{\mathrm{a}}$ & 0,510 & 0,462 & 2,151 \\
\hline
\end{tabular}

Tabel 14. Koefisien Determinan Menggunakan EXCEL

\begin{tabular}{|l|l|}
\hline \multicolumn{2}{|l|}{ Regression Statistics } \\
\hline Multiple R & 0,713853388 \\
\hline R Square & 0,50958666 \\
\hline $\begin{array}{l}\text { Adjusted R } \\
\text { Square }\end{array}$ & 0,462127304 \\
\hline Standard Error & 2,150745263 \\
\hline Observations & 35 \\
\hline
\end{tabular}

Berdasarkan tabel 13 dan 14 diatas menunjukkan bahwa diperoleh nilai $\mathrm{R}^{2}$ yang sama, yaitu sebesar 0,510 yang berarti bahwa variabilitas variabel user satisfaction yang dapat dijelaskan oleh variabel usability, information quality dan service interaction quality hanya sebesar 51\%. Sedangkan sisanya sebesar $49 \%$ dijelaskan oleh faktor lain yang tidak disertakan dalam penelitian ini.

\section{KESIMPULAN DAN SARAN}

\subsection{Kesimpulan}

Berdasarkan hasil analisis dan pembahasan yang sudah dilakukan, ditarik kesimpulan sebagai berikut:

1. Hasil yang didapat untuk hasil uji t variabel usability, t hitung < t tabel $(1,247<1,692)$ dan sig > 0,05. Hal ini menunjukkan $\mathrm{H}_{0}$ diterima dan $\mathrm{H}_{1}$ ditolak, atau tidak ada pengaruh yang signifikan usability terhadap user satisfaction. 
2. Hasil yang didapat untuk hasil uji t variabel information quality, $\mathrm{t}$ hitung $<\mathrm{t}$ tabel $(1,243<$ 1,692) dan sig > 0,05. Hal ini menunjukkan $\mathrm{H}_{0}$ diterima dan $\mathrm{H}_{2}$ ditolak, atau tidak ada pengaruh information quality yang signifikan terhadap user satisfaction.

3. Hasil yang didapat untuk hasil uji t variabel service interaction quality, $\mathrm{t}$ hitung $<\mathrm{t}$ tabel $(1,360<1,692)$ dan sig $>0,05$. Hal ini menunjukkan $\mathrm{H}_{0}$ diterima dan $\mathrm{H}_{3}$ ditolak, atau tidak ada pengaruh service interaction quality yang signifikan terhadap user satisfaction.

4. Hasil yang didapat untuk hasil uji $\mathrm{F}$ variabel usability, information quality, service interaction quality bersama-sama menunjukkan hasil bahwa terdapat pengaruh terhadap user satisfaction.

5. Hasil koefisien determinan $\mathrm{R}^{2}$ sebesar 0,510 yang dapat dijelaskan oleh variabel usability, information quality, service interaction quality sebesar 51\%. Sedangkan sisanya sebesar $49 \%$ dijelaskan oleh faktor lain.

6. Hasil penelitian keseluruhan menunjukkan kualitas dari layanan PPDB online di SMA Xaverius 2 Palembang belum cukup baik.

\subsection{Saran}

Berdasarkan hasil analisis dan pembahasan yang dilakukan, beberapa saran yang penulis berikan terhadap instansi maupun untuk penelitian selanjutnya, yaitu:

1. Dari ketiga variabel usability, information quality, service interaction quality semua variabel tidak ada yang berpengaruh terhadap kepuasan pengguna. Hal ini bisa menjadi catatan bagi penggurus website PPDB Online di SMA Xaverius 2 Palembang untuk terus meningkatkan kualitas dari website, baik dari sisi tampilan website dan isi dari website, sehingga kedepanya lebih baik lagi.

2. Rendahnya pemanfaatan website PPDB Online untuk proses pendaftarn peserta didik baru menjadi perhatian pihak sekolah untuk lebih mensosialisasikan sistem tersebut dan lebih meningkatkan kualitas website.

3. Pada penelitian ini peneliti hanya mengumpulkan data dari peserta didik. Pada penelitian selanjutnya sebaiknya juga mengumpulkan data dari sudut pandang pihak-pihak yang terkait lainnya. Serta dapat menambahkan variabel atau indikator baru yang tidak penulis gunakan dalam penelitian ini.

\section{DAFTAR PUSTAKA}

[1] L. A. Utami dan A. Ishaq, 2018, "Analisa Pengaruh Kualitas Website PPDB Terhadap Kepuasan Pengguna," Jurnal Penelitian. Teknik Informatika, Vol. 3, No. 1, pp. 31-37.

[2] Winarti dan L. C. Munggaran, 2014. "Pengukuran Kualitas Situs Perguruan Tinggi Dari Sudut Pandang Pemakai Dengan Menggunakan WEBQUAL 4.0," Jurnal Iliahu Informatika. Komputer Universitas Gunadarma, pp. 6-14.

[3] Tukino, 2019. “Analisis Kualitas Layanan Website SIKMB Menggunakan Metode Webqual 4.0 ( Studi pada BP Batam)," Kumpulan Jurnal Ilmu Komputer (KLIK), Vol. 06, No. 01, pp. 1-15.

[4] A. Al Baiti, Suprapto, dan A. Rachmadi, 2017. "Pengukuran Kualitas Layanan Website Dinas Pendidikan Kota Malang Dengan Menggunakan Metode Webqual 4.0 dan IPA," Jurnal Pengembangan Teknologi Inormasi dan Ilmu Komputer, Vol. 1, No. 9, p. 887.

[5] D. Y. Bernanda, B.A. Matjik, K. Christianto, L. Davinci, dan H. Hartono, 2019. "Analisis Kualitas Website Menggunakan Metode Webqual 4.0 pada Website Portal Universitas," Seminar Nasional Teknologi Fakultas Teknik Universitas 
Krisnadwipayana. 17 July.

[6] D. Novita, 2020, "Analisis Pengaruh Implementasi E-Learning Vilep di Poltekkes Kemenkes Palembang dengan Pendekatan EUCS," JATISI (Jurnal Teknik Informatika dan Sistem Informasi), Vol. 7, No. 1, pp. 29-41, doi: 10.35957/jatisi.v7i1.290.

[7] Dafid dan D. Novita, 2018, "Metode WebQual 4.0 Untuk Analisis Kualitas Web Pembelajaran," JTKSI, No. 01, No. 02, pp. 17-20.

[8] I. Ghozali, 2013, Aplikasi Analisis Multivariate dengan Program SPSS, 7th ed. Badan Penerbit Universitas Diponegoro, Semarang.

[9] Sugiyono, 2014, Metode Penelitian Pendidikan. Alfabet, Jakarta.

[10] G. Pramesti, 2017, “Statistika Penelitian Dengan SPSS 24,” Kompas Gramedia, Jakarta. 